\title{
Selective electrocatalysis of biofuel molecular oxidation using palladium nanoparticles generated on Shewanella oneidensis MR-1
}

Wu, Ranran; Tian, Xiaochun; Xiao, Yong; Ulstrup, Jens; Christensen, Hans Erik Mølager; Zhao, Feng; Zhang, Jingdong

Published in:

Journal of Materials Chemistry A

Link to article, DOI:

10.1039/C8TA01318G

Publication date:

2018

Document Version

Peer reviewed version

Link back to DTU Orbit

Citation (APA):

Wu, R., Tian, X., Xiao, Y., Ulstrup, J., Christensen, H. E. M., Zhao, F., \& Zhang, J. (2018). Selective electrocatalysis of biofuel molecular oxidation using palladium nanoparticles generated on Shewanella oneidensis MR-1. Journal of Materials Chemistry A, 6(23), 10655-10662. https://doi.org/10.1039/C8TA01318G

\section{General rights}

Copyright and moral rights for the publications made accessible in the public portal are retained by the authors and/or other copyright owners and it is a condition of accessing publications that users recognise and abide by the legal requirements associated with these rights.

- Users may download and print one copy of any publication from the public portal for the purpose of private study or research.

- You may not further distribute the material or use it for any profit-making activity or commercial gain

- You may freely distribute the URL identifying the publication in the public portal 


\section{Journal Name}

\section{ARTICLE}

\section{Selective electrocatalysis of biofuel molecular oxidation by palladium nanoparticles generated on Shewanella oneidensis MR-}

Received 00th January 20xx Accepted 00th January 20xx

DOI: $10.1039 / \times 0 \times x 00000 x$

www.rsc.org/

1

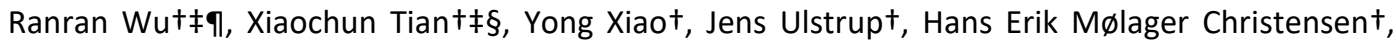
Feng Zhao ${ }^{*}$ and Jingdong Zhangt*

Production of molecular scale palladium (Pd) nanoparticles (NPs) is important due to their catalytic function in electrochemical oxidation of a number of core fuel molecules in fuel cells. Biogenetic methods offer an economic and environmentally friendly synthesis route. In this work, the electrochemically active bacterium Shewanella oneidensis MR-1 is employed as a reducing agent to generate PdNPs as well as a support for immobilization of the PdNPs. The synthesis was carried out at $28^{\circ} \mathrm{C}$ and $\mathrm{pH} 7.0$, and completed within one hour. The PdNPs are monodisperse $(6.2 \mathrm{~nm})$ and located on the bacterial membrane surface. Mapping by conductive atomic force microscopy shows that the presence of these PdNPs promotes electron transfer and enhances the electric conductivity of the cells. Compared to electrodeposited PdNPs, PdNPs generated by $S$. oneidensis MR-1 catalyzes electrochemically the oxidation of formate with $200 \mathrm{mV}$ less over potential. Notably they show unique selective activity toward electrochemical oxidation of formate, whereas no electrochemical catalysis was found for oxidation of ethanol, methanol, acetate, and formate. This work demonstrates a sustainable and low-cost method for producing efficient PdNPs catalysts with high catalytic selectivity.

\section{Introduction}

Noble metals such as Palladium (Pd) and platinum (Pt), are important catalysts in energy conversion, chemical reactions and abiotic electrochemical processes ${ }^{1,2}$. Nanoparticles (NPs) provide a large specific surface area, favourable electron density distribution, and reactive surface sites. They have been shown to assist effectively reduction/oxidation reactions of organic molecules ${ }^{3}$. Particularly, noble metal NPs are the most successful electrocatalysts for oxidation of small bio-organic molecules ${ }^{4}$, such as formic acid, ethanol, methanol, acetate and oxalate ${ }^{5,6}$. These cost friendly molecules can be used as fuels in fuel cells to convert chemical energy into electricity by electrochemical reactions ${ }^{7-9}$. Formation of PdNPs from inorganic Pd salt is a redox process and $50-150 \mathrm{~nm}$ PdNPs can

\footnotetext{
+ Department of Chemistry, Technical University of Denmark, 2800 Kongen Lyngby, Denmark

¥ CAS Key Laboratory of Urban Pollutant Conversion, Institute of Urban Environment, Chinese Academy of Sciences (CAS), 1799 Jimei Road, Xiamen 361021, China

$\S$ College of Chemistry \& Chemical Engineering, Xiamen University, Xiamen 361005, China

9) Tianjin Institute of Industrial Biotechnology, CAS, 32 West 7th Avenue, Tianjin Airport Economic Area, Tianjin 300308, China

Corresponding to jz@kemi.dtu.dk and fzhao@iue.ac.cn

Electronic Supplementary Information (ESI) available: [details of any supplementary information available should be included here]. See
} DOI: $10.1039 / x 0 x x 00000 x$ be prepared by electrodeposition in $3 \mathrm{M} \mathrm{HCl}^{10}$ or chemical synthesis ${ }^{11-12}$. However, only few of such PdNPs can catalyze selectively specific reactions ${ }^{13}$

Biosynthesis of metal NPs was emerged in late last century using Pseudomonas stutzeri for synthesis of silver-based crystalline nanoparticles ${ }^{14}$. The method is developing fast due to sustainability and environmentally friendly reaction conditions $^{15-16}$. Microorganisms such as Shewanella and Geobacter have been found to be highly reactive towards binding of metal ions ${ }^{17}$ and to induce precipitation of nanomaterials under mild conditions ${ }^{18}$. So far, the ability of producing PdNPs has been reported using a number of microbes such as Desulfovibrio desulfuricans ${ }^{19}$ and Escherichia coli $^{20}$. The cells were exposed to $\mathrm{Pd}(\mathrm{II})$ aqueous solution with dihydrogen, formate, or acetate as the electron donors. Notably, biogenic palladium nanostructures have been demonstrated to catalyze various reduction reactions including perchlorate degradation, chromate reduction, chlorophenol dehalogenation ${ }^{19-22}$, and reductive dehalogenation of polychlorinated biphenyl congeners in sediment and aqueous matrices ${ }^{23}$. In addition, biogenic PdNPs were reported to serve as effective catalysts in the synthesis of organic compounds ${ }^{19,24}$. Due to poor intrinsic conductivity of the bacterial cells, carbonization of the cells was employed so that the PdNPs could be used as electrocatalysts. A binder such as Nafion also had to be employed to fix the PdNPs firmly on the electrode surface ${ }^{25}$. 
Shewanella oneidensis MR-1 belongs to a class of Gramnegative bacteria and is chosen as a target microorganism in the present work due to its unique electrochemical activity ${ }^{26-}$ 27. S. oneidensis MR-1 can transfer electrons from the inner to the outer membrane, and eventually to exogenous electron acceptors ${ }^{28}$, resulting in the reduction of metal ions. While cytochrome $c$ plays an important role in the reduction of iron and silver, several studies have demonstrated that hydrogenases play a leading role in microbial $\mathrm{Pd}(\mathrm{II})$ reduction ${ }^{29,30}$. Specifically, the hydrogenases but not cytochrome $c$, are mainly responsible for $\mathrm{Pd}(\mathrm{II})$ reduction in $S$. oneidensis $\mathrm{MR}-1^{31}$. In addition, extracellular polymeric substances (EPS) of Shewanella biofilm contain over 20 redox active proteins ${ }^{32,33}$. Our recent work showed that EPS in this strain were transient media for microbial extracellular electron transfer ${ }^{34}$.

S. oneidensis has shown its ability to biosynthesize metallic ( $\mathrm{Fe}$, $\mathrm{Au}$ ) nanomaterials by reduction or adsorption of metal ions or complexes from the surrounding medium ${ }^{35,36}$. Recently, highlyporous heteroatom-doped carbon with well-dispersed $150 \mathrm{~nm}$ PdNPs has been developed through biogenic reduction on $S$. oneidensis and activation at $420{ }^{\circ} \mathrm{C}$ in $\mathrm{KOH}$ and found to electrocatalyze strongly the electrochemical dioxygen reduction reaction ${ }^{9}$. Furthermore, formic acid $(\mathrm{HCOOH})$ is an organic biomolecule widely used in chemical industry and a byproduct in the manufacture of other chemicals. Electrochemical oxidation of formic acid (FA) is another core anodic reaction in FA fuel cells.

In this work we develop a method for synthesizing small PdNPs as electrocatalysts under mild conditions using $S$. oneidensis MR-1. Here the bacterial cells serve as electron donors (as reducing agent) and supporting materials for immobilization of the formed PdNPs. Microscopic techniques such as transmission electron (TEM), atomic force microscopy (AFM) and particularly current sensing AFM are employed to map the structures and compositions of S. oneidensis MR-1 and PdNPs. We find that the presence of the PdNPs increases significantly the electric conductivity of the biological cells. The PdNPs prepared and immobilized on S. oneidensis MR-1 show strong electrochemical catalysis specifically toward oxidation of formic acid, but no catalysis for other small organic fuel molecules, ethanol, methanol, and acetate. Such selectivity is unique and important for development of FA fuel cells.

\section{Experimental section}

\section{Chemicals}

Sodium tetrachloropalladate (98\%, Sigma-Aldrich), sodium lactate (98\%, Sigma-Aldrich L7022), sodium formate (99.0\%, Fluka), sodium acetate (99.0\%, Sigma-Aldrich), methanol (99.9\%, Sigma-Aldrich), ethanol (99.9\%, Uvasol), Luria-Bertani (LB) Broth (L3022, Sigma-Aldrich) were used without further purification. Phosphate buffer solution (PBS) was prepared from potassium phosphate salts $\left(\mathrm{KH}_{2} \mathrm{PO}_{4}, 99.995 \%\right.$; $\mathrm{K}_{2} \mathrm{HPO}_{4}$, 99.999\%; Fluka). The precise $\mathrm{pH}$ was measured by $\mathrm{pH}$ meter
All solutions were prepared with ultrapure water (18.2 $\mathrm{M} \Omega \cdot \mathrm{cm})$.

\section{Bacterial growth and $\mathbf{P d}$ (II) bioreduction assay}

Shewanella oneidensis MR-1 from ATCC (USA) was grown aerobically in LB medium overnight at $28{ }^{\circ} \mathrm{C}$. The cells were then harvested and transferred into sterile $50 \mathrm{ml}$ centrifuge tubes by centrifuging at $4000 \mathrm{rpm}$ for $10 \mathrm{~min}$, followed by washing three times with phosphate buffer $(50 \mathrm{mM}, \mathrm{pH} 7.0)$. The washed cells were resuspended with $40 \mathrm{ml}$ lactate medium in glass serum bottles. Serum bottles were capped with inert viton stoppers. A control reactor containing no cells was set up in parallel. Bioreduction assays that excluded dioxygen were flushed with $\mathrm{N}_{2}$ for $30 \mathrm{~min}$. Finally, $0.20 \mathrm{mM}$ sodium tetra-chloropalladate(II) was added to the bioreduction assay. The serum bottles were then incubated overnight at $28{ }^{\circ} \mathrm{C}$. $\mathrm{pH}$ in all assays remained 7.0 \pm 0.1 and all assays were performed in triplicates.

\section{UV-vis spectroscopy}

Ultraviolet-visible (UV-vis) absorption spectra were recorded for different bacterial and chemical solutions using quartz cells and an Agilent 8453 UV-vis spectrophotometer.

\section{Transmission electron microscopy (TEM)}

Samples for TEM were prepared by transferring the cells from sealed batch cultures and immediately fixing the cells by glutaraldehyde solution ( $2.5 \%$ final concentration). Samples were then subjected to a serial dehydration protocol using increasing concentrations of ethanol and placed onto a carbon coated copper grid. After drying at $60{ }^{\circ} \mathrm{C}$ for $24 \mathrm{~h}$, the desiccated samples were imaged by a transmission electron microscope (Tecnai G2 F30, Philips-FEl, Netherlands).

\section{X-ray diffraction (XRD) and sample preparation}

After the exposure to sodium tetrachloropalladate, $S$. oneidensis MR-1 was collected by centrifugation at $8000 \mathrm{xg}$ for $10 \mathrm{~min}$, and washed three times with ultrapure water. The cells were then dried at $60{ }^{\circ} \mathrm{C}$. A X-ray diffractometer (X'Pert PRO, PANalytical) was employed for XRD analysis to determine the composition of the nanoparticles. Each sample was scanned in the $\theta$-range of $5-90^{\circ}$.

\section{Atomic Force Microscopy (AFM), sample preparation, and image acquisition.}

Bacterial cells were collected by centrifugation $(8000 \mathrm{xg}, 10$ $\mathrm{min})$, and washed three times with ultrapure water. The cell resuspension was dropped on a platinum sheet $\left(1.0 \times 1.0 \mathrm{~cm}^{2}\right)$ and dried at room temperature. A PicoScan 5500 instrument (Agilent Technologies, Chandler, AZ, USA) with an $80 \mu \mathrm{m}$ scanner and cantilevers (NP-S) from Veeco (Camarillo, CA, USA) were used to obtain the AFM images. Contact mode was used to record all the signals. All AFM images shown are representative of a large number of images under the same conditions. The contact mode AFM (Pico View, Agilent) with a 
current-sensing module, known as current sensing AFM (CSAFM), was utilized to obtain simultaneously topography, deflection and current images. Chromium-platinum ( $\mathrm{Cr} / \mathrm{Pt}$ ) coated cantilevers (spring constant, $0.2 \mathrm{~N} / \mathrm{m}$ ) were from Budget Sensors (Sofia, Bulgaria). The load force applied was less than $10 \mathrm{nN}$ to avoid damage of samples and the conductive tip. The bias voltage between conductive cantilever and substrate $(\mathrm{Pt})$ was $50 \mathrm{mV}$ in all imaging experiments.

\section{Electrode preparation and electrochemical measurements}

Cells of $S$. oneidensis MR-1 were collected by centrifugation at $8000 \mathrm{xg}$ for $5 \mathrm{~min}$, and washed three times with phosphate buffer $(50 \mathrm{mM}, \mathrm{pH} 7.0) .5 \mu \mathrm{L}$ of cell pellet was transferred to the surface of a glassy carbon (GC) electrode and dried at room temperature.

A three-electrode glass cell with the prepared GC working electrode, a saturated calomel (SCE) reference electrode and a Pt wire counter electrode confined in a Faraday cage was used for the electrochemical measurements. Cyclic voltammetry was carried out using an Autolab potentiostat (The Netherlands). The scan rate was $10 \mathrm{mV} / \mathrm{s}$. All electrochemical tests were repeated at least 5 times and all measured potentials are reported vs SCE. Phosphate buffer $(50 \mathrm{mM}, \mathrm{pH}$ 7.0) was used as electrolyte. Argon $(5.0 \mathrm{~N})$ was used to deoxygenate all solutions for at least $30 \mathrm{~min}$ and an argon stream was kept flowing over the solutions.

\section{Results and discussion}

\section{Biosynthesis of PdNPs}

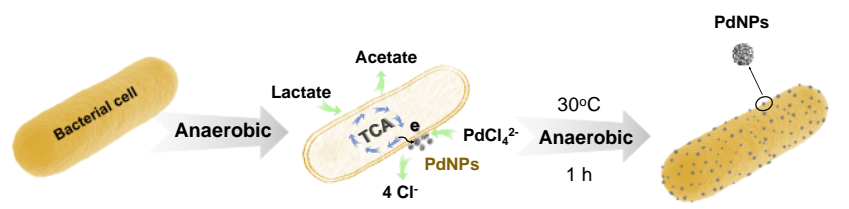

Scheme 1. Illustration of the biosynthesis of PdNPs on $S$. oneidensis MR-1.

The process of biogenic synthesis of PdNPs using S. oneidensis MR-1 is presented schematically in Scheme 1 . The bacterial cells serve as reducing agents for reduction of $\left[\mathrm{PdCl}_{4}\right]^{2-}$ to PdNPs as well as a support for immobilization of the freshly formed PdNPs. The colour of the S. oneidensis MR-1 containing medium changed from light yellow into dark brown within 10 min (Figure 1, A and B) after the injection of aqueous $\mathrm{Na}_{2}\left[\mathrm{PdCl}_{4}\right]$. The rapid formation of PdNPs on $S$. oneidensis cells is due to high hydrogenase content in the cells ${ }^{37}$. A series of UV-vis spectra indicate that the synthesis is complete (Figure (1C). Aqueous $\mathrm{Na}_{2}\left[\mathrm{PdCl}_{4}\right]$ solution itself showed a distinct absorption peak at $411 \mathrm{~nm}$. When the solution colour changed into dark brown, the $\left[\mathrm{PdCl}_{4}\right]^{2-}$ absorption peak disappears totally. Bacteria-free solution still showed the $411 \mathrm{~nm}$ absorption peak in the same time interval, though the peak became narrower. This shows clearly that the reduction was conducted due to $S$. oneidensis MR-1 rather than any chemical component in the medium.

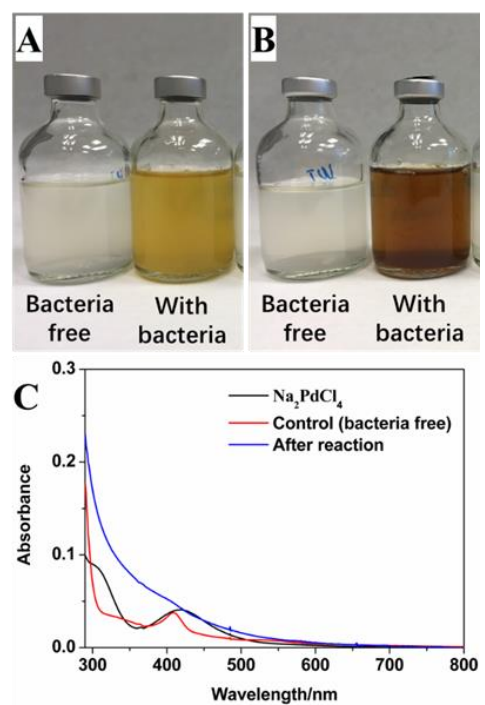

Figure 1. Photos of the solutions (A) before and (B) after the reaction of bacteria with $\mathrm{Na}_{2}\left[\mathrm{PdCl}_{4}\right]$; (C) UV-vis spectra of $\mathrm{Na}_{2}\left[\mathrm{PdCl}_{4}\right]$ (black line), control experiment without bacteria (red line), and supernatant of the bacterial solution after reaction (blue line). $\mathrm{OD}_{600}$ of the bacterial solution was 0.6 and the final concentration of $\mathrm{Na}_{2}\left[\mathrm{PdCl}_{4}\right]$ was $0.10 \mathrm{mM}$.

\section{Properties of bio-PdNPs}

The presence and composition of PdNPs were further mapped by scanning transmission electron microscopy (STEM). Representative images of bacterial cells and the biosynthetic PdNPs at a $\mathrm{Na}_{2}\left[\mathrm{PdCl}_{4}\right]$ concentration of $0.4 \mathrm{mM}$ are shown in Figure 2. When the cells were exposed to $\mathrm{Na}_{2}\left[\mathrm{PdCl}_{4}\right]$ solution, highly dispersed NPs were observed on the bacterial cell surface. The size of the PdNPs was determined to be in the 3$10 \mathrm{~nm}$ range with an average diameter of $6.2 \mathrm{~nm}$ (Figure S1). The size and distribution of PdNPs are highly reproducible both within a single sample and among different samples with the same treatment. Compared with the High-Angle-Annular-DarkField (HAADF) micrograph, the single cell can be distinguished by the presence of biologically common chemical elements such as carbon, nitrogen and phosphorous. After formation, the composition of the nanoparticles was determined and the $\mathrm{Pd}$ element distribution found to match well the shape of the bacterial cell (Figure 2E and F). X-ray diffraction (XRD) was employed to further determine the valence state of the biogenetic PdNPs (Figure S2). Five new peaks occurred after the cells had been exposed to $1 \mathrm{mM} \mathrm{Na}_{2}\left[\mathrm{PdCl}_{4}\right]$ solution. By comparing with standard PDF card [JCPDS file no. 03-056174 .], these emerging peaks at $2 \theta=40.230^{\circ}, 46.651^{\circ}, 68.119^{\circ}$, $82.050^{\circ}$ and $86.672^{\circ}$, are assigned to $\operatorname{Pd}(111), \operatorname{Pd}(200), \operatorname{Pd}(220)$, $\mathrm{Pd}(311)$ and $\mathrm{Pd}(222)$ reflections, respectively. These results confirm that PdNPs had been formed on the S. oneidensis MR1 surface. 


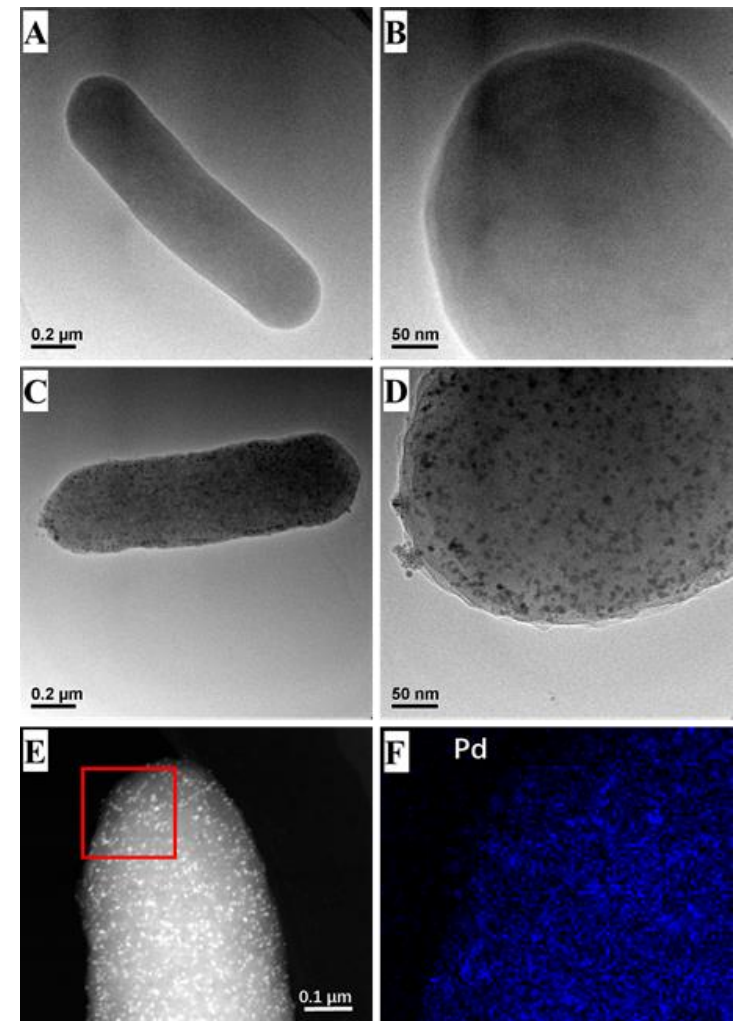

Figure 2. TEM images of a $S$. oneidensis $M R-1$ cell $(A, B)$ before and (C, D) after the bio-reduction of Pd(II); (E) HAADF image of a $S$. oneidensis MR-1 cell after PdNP formation and (F) EDS mapping of the red box area in E showing clusters mainly composed of palladium (blue points).

\section{Dynamics of the biogenic PdNP synthesis}

The formation of PdNPs is a redox process when palladium salt is in contact with reducing agents in the solution. The redox potential of the solution therefore changes during consumption of the oxidation agent and can be measured by chronopotentiometry. $\mathrm{Na}_{2}\left[\mathrm{PdCl}_{4}\right]$ solution with a yellow colour was reduced to palladium atoms, which further underwent nucleation and growth to develop into PdNPs with a deep brown colour. The reduction process can be described by equation 1.

$$
\begin{aligned}
& {\left[\mathrm{PdCl}_{4}\right]^{2-}+2 \mathrm{e}^{-} \rightarrow \mathrm{Pd}(0)+4 \mathrm{Cl}^{-}} \\
& \mathrm{E}^{\circ}=+0.915 \mathrm{~V} \text { (vs. SHE) }
\end{aligned}
$$

The reaction was accompanied by equilibrium potential changes in the solution. The time-dependent potential represents the development of the ratio between the oxidized and reduced forms, thus reflecting the dynamics of the reduction process ${ }^{38}$. The time dependence of the potential was dominated by reduction of $\mathrm{Na}_{2}\left[\mathrm{PdCl}_{4}\right]$. The potential value of $\mathrm{Na}_{2}\left[\mathrm{PdCl}_{4}\right]$ is different from that of the buffer and bacterial cells, and equilibrates much faster.

To investigate the biosynthesis process, indium tin oxide (ITO) and saturated calomel electrode (SCE) were used as working and reference electrode. Anaerobic condition was achieved by bubbling Ar gas for $40 \mathrm{~min}$. Bare ITO or bacteria coated ITO was initially inserted into the phosphate buffer (lactate, 5 $\mathrm{mM}$ ), followed by recording the open circuit potential (OCP) between the working and reference electrode during the reaction. When the potential reached a stable value, a certain amount of $0.20 \mathrm{mM} \mathrm{Na}_{2}\left[\mathrm{PdCl}_{4}\right]$ solution (final concentration) was injected in $10 \mathrm{ml}$ medium solution. Figure 3 shows several examples of time-dependent potential evolution at different $\mathrm{Na}_{2}\left[\mathrm{PdCl}_{4}\right]$ concentrations. The time evolution of the OCP is complex, and several kinetic phases can be clearly distinguished, as reported for AuNP formation via $\left[\mathrm{AuCl}_{4}\right]^{-}$ reduction by 2 -(N-morpholino)ethanesulfonic acid $(\mathrm{MES})^{38}$. The OCP for bare ITO increased from $0.01 \mathrm{~V}$ to $0.31 \mathrm{~V}$ immediately after $\mathrm{Na}_{2}\left[\mathrm{PdCl}_{4}\right]$ addition and kept at a relatively stable value $(0.29 \mathrm{~V})$ for a long time. The slight decrease in potential right after addition was caused by diffusion of $\mathrm{Na}_{2}\left[\mathrm{PdCl}_{4}\right]$ in the bacteria-free medium. For bacteria coated ITO, the potential rose steeply after adding $\mathrm{Na}_{2}\left[\mathrm{PdCl}_{4}\right]$. At lower $\mathrm{Na}_{2}\left[\mathrm{PdCl}_{4}\right]$ concentration $(0.1 \mathrm{mM}, 0.2 \mathrm{mM})$, the OCP increased less and reached a maximum in 100-150 seconds, while at higher $\mathrm{Na}_{2}\left[\mathrm{PdCl}_{4}\right]$ concentrations $(0.3 \mathrm{mM}, 0.4 \mathrm{mM})$, the OCP increased rapidly and reached its maximum in about 50 seconds followed by a decay. The potential decay was slow and changed slightly at low $\mathrm{Na}_{2}\left[\mathrm{PdCl}_{4}\right]$ concentration, but was much faster at a higher concentration with a slower further decay appearing after $250 \mathrm{~s}$.

Although with clearly distinct kinetic phases as for AuNP formation by MES reduction ${ }^{38}$, the overall shape of the chronopotentiometric curves are different. Fast and slow potential increases were found on initial stage of AuNP formation followed again by biphasic potential decay ${ }^{38}$. Such a pattern was attributed to formation of the intermediate $\left[\mathrm{AuCl}_{2}\right]^{-}$prior to formation of $\mathrm{Au}$ atoms during the early stage of the synthesis process ${ }^{38}$. Here we conclude that $\mathrm{Na}_{2}\left[\mathrm{PdCl}_{4}\right]$ reduction occurs due to certain compounds on the $S$. oneidensis MR-1 cell surface. We note that the OCP decrease ends within $250 \mathrm{~s}$ and reached a stable value in $1200 \mathrm{~s}$, implying that the reduction reaction is complete. This observation accords with the colour change of the bacterial solution in contact with $\mathrm{Na}_{2}\left[\mathrm{PdCl}_{4}\right]$. Further, the final OCP value depends on the starting concentration of $\mathrm{Na}_{2}\left[\mathrm{PdCl}_{4}\right]$, i.e. the OCP using $0.40 \mathrm{mM}$ was higher than that using $0.30 \mathrm{mM}$, although the net increases were small $(0.49 \mathrm{~V}$ and $0.51 \mathrm{~V}$, respectively). 


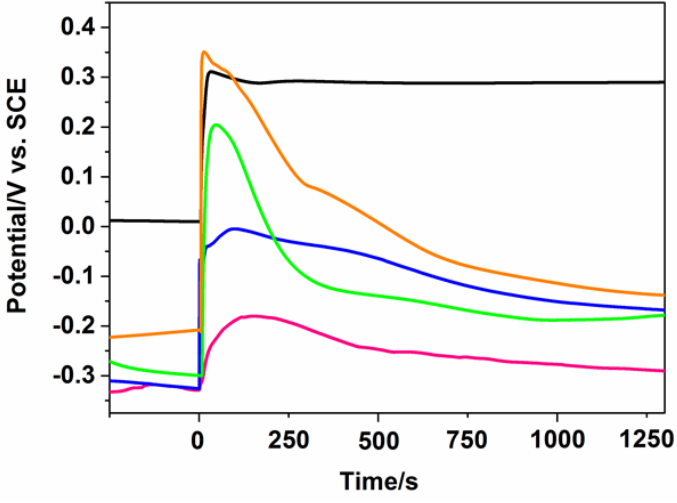

Figure 3. Time dependent potential change during the biosynthesis of PdNPs. $\mathrm{Na}_{2}\left[\mathrm{PdCl}_{4}\right]$ (final concentration $0.2 \mathrm{mM}$ ) was injected $(0 \mathrm{~s})$ to each solution at room temperature. Addition of a final concentration of $0.2 \mathrm{mM} \mathrm{Na}_{2}\left[\mathrm{PdCl}_{4}\right]$ to a bare ITO electrode was used as a control experiment (Black line). Bacterial cell coated ITO after addition of 0.1 (Red line), 0.2 (Blue line), 0.3 (Green line), and 0.4 (yellow line) $\mathrm{mM}$ $\mathrm{Na}_{2}\left[\mathrm{PdCl}_{4}\right]$ were recorded. Magnetic stirring was maintained throughout. $50 \mathrm{mM}$ phosphate buffer $(\mathrm{pH}$ 7.0) was used as supporting electrolyte.

\section{Enhancement of cell conductivity}

Current Sensing-AFM (CS-AFM) provides information on the correlation between the sample morphology and characteristic current pathways ${ }^{39}$. Herein, CS-AFM (in air) was employed for the study of $S$. oneidensis MR-1 cells before and after PdNPS biosynthesis to investigate changes in cell conductivity. A polished platinum sheet was used as a conductive supporting material. Bacterial cells with or without PdNPs were drop cast on the platinum sheet which was electrically insulated from the sample plate. A copper wire served as an electrode to connect the sample plate and the platinum sheet. A conductive AFM tip coated with $\mathrm{Pt} / \mathrm{Cr}$ was used to image topography and corresponding currents that flow vertically through the cells by contacting the cells. A small bias voltage $(50 \mathrm{mV})$ between the tip and the substrate was applied when the tip was scanning horizontally over the samples. The vertical currents at each point are relevant in evaluating the electrical properties of the bacterial cells.

Figure 4 shows typical topographic and current images simultaneously obtained for $S$. oneidensis MR-1 cells in the presence/absence of PdNPs. In the topographic images, flat surfaces for Pt sheets were observed and the $S$. oneidensis MR1 cells feature of were seen clearly. The bacterial cell surface is relatively rough regardless of with or without PdNPs. It is hard to distinguish PdNPs on the cells in topography AFM images due to their small size and the curvature of the bacterial surface, Figure S3. On the other hand, current-sensing AFM (CSAFM) can distinguish clearly different conductivity of the PdNP free and PdNP modified bacterial cells. Bright regions in the CSAFM images represent currents flowing vertically from the tip to the substrate while dark spots show insulating regions. Under the conditions used, these current flow patterns were observed in all samples. Pure bacterial cells exhibit obvious morphology in topography and appear dark in current images, indicating poor conductivity. The cell height was measured by the AFM cross section profile. In the presence of PdNPs, the bacterial cells showed weak electric currents, demonstrating enhanced electric conductivity, due to enhanced electronic charge transport (tunnelling, or hopping) by PdNPs. CS-AFM images thus show clearly highly conspicuous conductivity increases induced by the PdNPs.

A
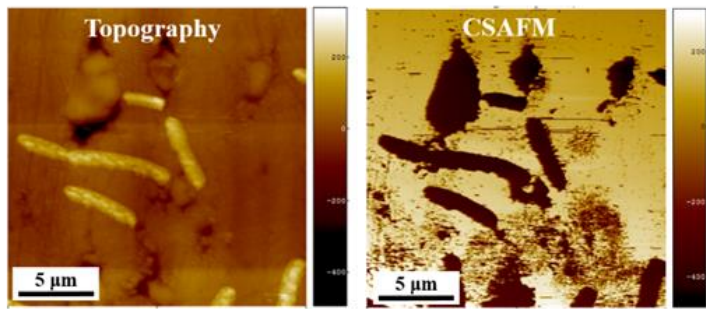

B
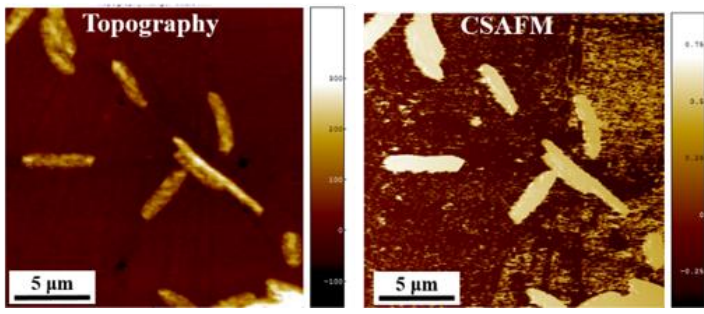

Figure 4. AFM images of typical topography and currentsensing AFM (CSAFM) image for natural $S$. oneidensis MR-1 cells (A) and S. oneidensis MR-1 cells with PdNPs (B). The scan area was $20 \times 20 \mu \mathrm{m}^{2}$.

\section{Selective catalysis toward electrochemical oxidation of formate}

The electrocatalysis of the electrochemical oxidation reactions of several (bio)fuel molecules with the conducting $S$. oneidensis MR-1 cells with PdNPs on glassy carbon (GC) electrode as heterogeneous catalysts was investigated. Figure 5A shows cyclic voltammograms of electrodeposited $\mathrm{Pd}$ on glassy carbon electrode in $0.10 \mathrm{M}$ formate at room temperature. There is a strong anodic peak at $0.15 \mathrm{~V}$ as a characteristic feature for catalysis of electrochemical formate oxidation. A dual pathway mechanism for formic acid oxidation with $\mathrm{Pd}$ or Pt-based catalyst is commonly accepted ${ }^{40,41}$. The direct pathway via a dehydrogenation is the more desirable, as a reactive intermediate is formed in this pathway. Another reaction pathway is an indirect path via dehydration in which adsorbed $\mathrm{CO}$ as an intermediate catalyst poisoning species is formed. The voltammetric pattern of the electrochemical oxidation of formate is featured by two distinct anodic current peaks, one in the forward potential scan, and the other one in the reverse scan. This one-peak graph is characteristic of the direct formate oxidation pathway, in which $\mathrm{HCOOH}$ loses two $\mathrm{H}$-atoms, at the same time generating $\mathrm{CO}_{2}$ and $\mathrm{H}^{+}$, equation (2):

$$
\mathrm{HCOOH} \rightarrow 2 \mathrm{H}^{+}+\mathrm{CO}_{2}+2 \mathrm{e}^{-}
$$

In contrast, there are three peaks in the absence of formate in the forward scan, corresponding to different electrochemical processes at the $\mathrm{Pd}$ surface. The redox peaks on $\mathrm{Pd}$ at the 
potential $-0.6 \mathrm{~V}$, are caused by the oxidation of adsorbed and desorbed hydrogen ${ }^{41}$. The second peak, at $-0.4 \mathrm{~V}$ is attributed to the adsorption of $\mathrm{OH}^{-42,43}$, while the third peak above $0.1 \mathrm{~V}$ is assigned to the formation of the palladium(II) oxide ${ }^{44}$.
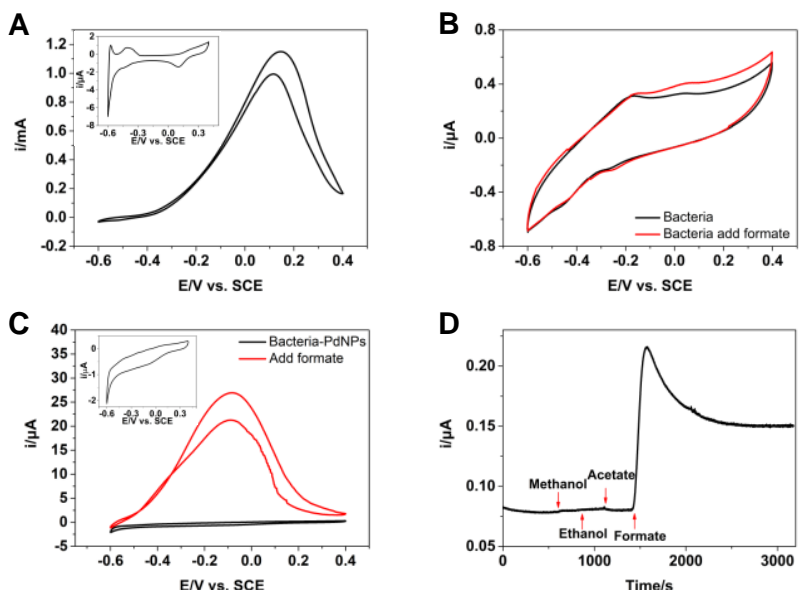

Figure 5. Cyclic voltammograms of (A) electrodeposited $\mathrm{Pd}$ on GC electrode; pure $S$. oneidensis MR-1 on GC (B) and (C) $S$. oneidensis MR-1 with bio-PdNPs on GC electrode in in $0.10 \mathrm{M}$ formate and $0.10 \mathrm{M} \mathrm{pH} 7.0$ phosphate buffer solution. Scan rate $10 \mathrm{mV} / \mathrm{s}$; and (D) chronoamperometric curve of methanol, ethanol, acetate, and formate oxidation at S. oneidensis MR-1 with bio-PdNPs and the potential held at $-0.1 \mathrm{~V}$. Final concentrations of methanol, ethanol, acetate, and formate are $0.10 \mathrm{M}$. Inset figures in (A) and (C) show CVs of electrodeposited Pd and PdNPs-cells on GC in $0.10 \mathrm{M} \mathrm{pH} 7.0$ PBS, respectively.

The CVs in Figure 5B show the redox reaction from the cells and formate. The $\mathrm{CV}$ of $S$. oneidensis MR-1 exhibits a pair of electrochemical peaks at $+0.05 \mathrm{~V}$ and $-0.23 \mathrm{~V}$. These are caused by cytochrome $c$. Addition of formate did not generate any strong anodic peak, i.e. electrocatalysis of formate oxidation did not occur with S. oneidensis MR-1. The oxidation current was slightly increased probably due to formate oxidation by the respiration of the cells. This result shows that pure S. oneidensis MR-1 cells cannot catalyse oxidation of formate electrochemically, but are able to use it as an electron donor.

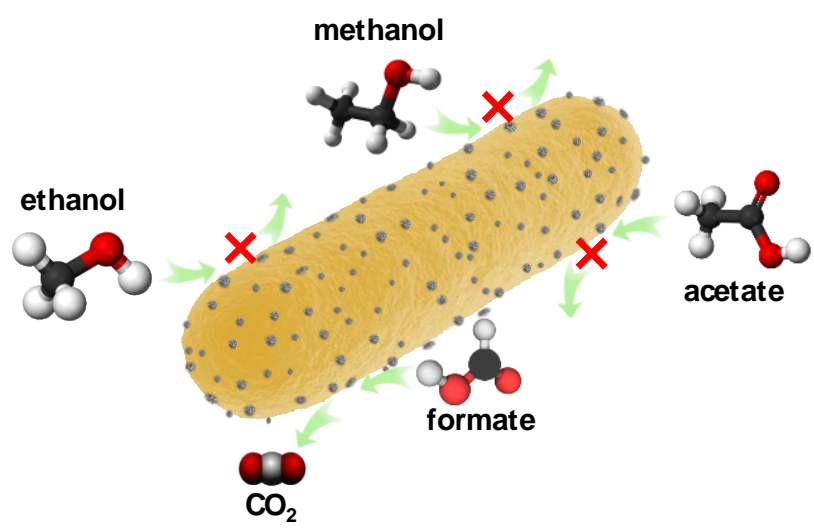

Scheme 2. Selective catalysis of fuel molecule oxidations on the bio-PdNPs.

Notably, formate oxidation on PdNPs-cell coated GC electrode gives a similar CV pattern as on electrodeposited Pd, but with more than an order of magnitude larger current, Figure $5 \mathrm{C}$. In the forward scan, formate oxidation begins from $-0.60 \mathrm{~V}$ with one strong anodic peak at $-0.10 \mathrm{~V}$. In the cathodic scan, the anodic current started at $0.20 \mathrm{~V}$, and reaches a maximum at $0.10 \mathrm{~V}$. This distinct current peak is related to the removal of carbonaceous substances that were not completely oxidized in the forward scan rather than the oxidation of freshly chemisorbed substance. The high oxidation current observed in the reverse potential sweep is attributed to the regeneration of the active PdNPs surface sites. We note that the anodic formate oxidation peak is $220 \mathrm{mV}$ more negative on biogenetic PdNPs than on electrodeposited Pd, suggesting less activation energy needed and better electrocatalysis on PdNPs-cells achieved.

High catalytic activity of the biogenetic PdNPs could be caused by the combination of PdNPs with bacterial membrane proteins. Such high catalytic activity is unique and the physical origins of this efficient electrocatalysis is under investigation. We can conjecture that bacterial proteins with multiple electronic and electron transfer systems could affect the three-dimensional electronic PdNP structure, leading to more easily adsorbed formate molecules and dehydration to produce $\mathrm{CO}_{2}$ on the PdNPs. The proteins may also weaken the adsorption of the $\mathrm{CO}$ intermediate on the Pd surface, thus reducing poisoning of the bio-PdNPs. $\mathrm{CO}$ is thus a catalytic poison formed and adsorbed on the Pd surface at higher potentials ${ }^{2}$. Our results strongly suggest that the PdNPs formed by $S$. oneidensis MR-1 cells are suitable catalysts with excellent and highly selectivity in formate oxidation. No electrocatalysis was observed for methanol, ethanol, and acetate (Figure S4). This is further confirmed by chronoamperometry. Figure 5D shows that the current is maintained constant after the addition of methanol, ethanol and acetate, but a drastic current increase from 0.08 to 0.22 $\mu \mathrm{A}$ appears after injection of formate. This shows clearly that the bio-PdNPs on $S$. oneidensis MR-1 cells have unique selectivity towards formate oxidation. As a control, experiments using electro-deposited PdNPs, current responses occurred whenever methanol, ethanol, acetate or formate was added (Figure S5), revealing that the electro-deposited PdNPS do not give selective catalysis toward oxidation of formate. The effect of the PdNPs size in formic acid catalytic oxidation has been reported previously. Zhou ${ }^{45}$ showed that 5-7 nm PdNPs offer the best eletrocatalysis and that the catalysis mainly follows the direct oxidation mechanism. The current findings indicate that the bio-PdNPs selectively catalyse formate electrochemical oxidation. They offer, therefore a perspective for use as novel electrocatalysts in formate acid fuel cells or formate sensors. A scheme for the selective catalysis of bio-PdNPs that involved preferential binding of 
formate but not of methanol, ethanol, and acetate on active sites of S. oneidensis bound PdNPs. is shown in Scheme 2.

\section{Conclusions and perspectives}

Shewanella oneidensis MR-1 cells provide a facile reduction process for preparing molecular scale PdNPs, and act as a natural support for the biosynthesized PdNPs. The presence of PdNPs on $S$. oneidensis MR-1 cells increase significantly the electronic conductivity of the cells. PdNPs were uniformly dispersed on the bacterial surface and exhibited superior activity for electrochemical oxidation of formate with high selectivity and no activity for the other (bio)fuel molecules methanol, ethanol, and acetate. These findings offer potential applications for metal-reducing bacteria and biosynthetic nanomaterials, and the PdNPs developed in this work could be useful in fields of industrial catalysis, environmental metal remediation and energy conversion. Further studies on the molecular mechanisms of the selective electrocatalysis of these biosynthetic PdNPs are being pursued.

\section{Conflicts of interest}

There are no conflicts to declare. The manuscript was written through contributions of all authors. All authors have given approval to the final version of the manuscript.

\section{Acknowledgements}

Financial support from Universities Denmark to R. W., the Carlsberg foundation (CF15-0164) to Y. X., Xiamen University to $X$. T., National Natural Science Foundation of China (21777155) F. Z., (51478451) to Y. X., and Otto Mønsted Foundation to J. Z. is gratefully appreciated.

\section{References}

1 Guo, S.; Zhang, S.; Su, D.; Sun, S., Seed-mediated synthesis of core/shell FePtM/FePt (M = Pd, Au) nanowires and their electrocatalysis for oxygen reduction reaction. J. Am. Chem. Soc. 2013, 135, 13879-84.

2 Kannan, P.; Dolinska, J.; Maiyalagan, T.; Opallo, M., Facile and rapid synthesis of $\mathrm{Pd}$ nanodendrites for electrocatalysis and surface-enhanced Raman scattering applications. Nanoscale 2014, 6, 11169-76.

3 Zhang, F. F.; Zhou, D. B.; Zhou, M. D., Ethanol electrooxidation on $\mathrm{Pd} / \mathrm{C}$ nanoparticles in alkaline media. Journal of Energy Chemistry 2016, 25, 71-76.

4 Jensen, K. S. S.; Sun, H.; Werchmeister, R. M. L.; Mølhave, K.; Zhang, J., Microwave synthesis of metal nanocatalysts for the electrochemical oxidation of small biomolecules, Current Opinion in Electrochemistry, Current Opinion in Electrochemistry 2017, 4, 124-132.

5 Greeley, J.; Stephens, I. E.; Bondarenko, A. S.; Johansson, T. P.; Hansen, H. A.; Jaramillo, T. F.; Rossmeisl, J.; Chorkendorff, I.; Norskov, J. K., Alloys of platinum and early transition metals as oxygen reduction electrocatalysts. Nat. Chem. 2009, 1, 552-6.
6 Wu, G.; Li, D.; Dai, C.; Wang, D.; Li, N., Well-dispersed high-loading pt nanoparticles supported by shell-core nanostructured carbon for methanol electrooxidation. Langmuir 2008, 24, 3566-75.

7 Kim, Y. H.; Campbell, E.; Yu, J.; Minteer, S. D.; Banta, S., Complete oxidation of methanol in biobattery devices using a hydrogel created from three modified dehydrogenases. Angew. Chem. Int. Ed. 2013, 52, 1437-40.

8 Nick L. Akers, C. M. M., Shelley D. Minteer, Development of alcohol $/ \mathrm{O}_{2}$ biofuel cells using saltextracted tetrabutylammonium bromide/Nafion membranes to immobilize dehydrogenase enzymes. Electrochim. Acta 2005, 50, 2521-2525.

9 Sakai, K.; Kitazumi, Y.; Shirai, O.; Takagi, K.; Kano, K., High-power formate/dioxygen biofuel cell based on mediated electron transfer type bioelectrocatalysis. ACS Catalysis 2017, 7, 5668-5673.

10 Diculescu, V. C.; Chiorcea-Paquim, A. M.; Corduneanu, O.; Oliveira-Brett, A. M., Palladium nanoparticles and nanowires deposited electrochemically: AFM and electrochemical characterization. J. Solid State Electrochem. 2007, 11, 887-898.

11 Wang, M.; Ma, Z. Z.; Li, J. P.; Zhang, Z. H.; Tang, B.; Wang, X. G., Well-dispersed palladium nanoparticles on nickel- phosphorus nanosheets as efficient threedimensional platform for superior catalytic glucose electro-oxidation and non-enzymatic sensing. J. Colloid Interface Sci. 2018, 511, 355-364.

12 Deroco, P. B.; Melo, I. G.; Silva, L. S. R.; Eguiluz, K. I. B.; Salazar-Banda, G. R.; Fatibello, O., Carbon black supported Au-Pd core-shell nanoparticles within a dihexadecylphosphate film for the development of hydrazine electrochemical sensor. Sensor. Actuat. BChem. 2018, 256, 535-542.

13 Wang, H. B.; Thia, L.; Li, N.; Ge, X. M.; Liu, Z. L.; Wang, X., Pd Nanoparticles on Carbon Nitride-Graphene for the Selective Electro-Oxidation of Glycerol in Alkaline Solution. ACS Catal. 2015, 5, 3174-3180.

14 Klaus, T.; Joerger, R.; Olsson, E.; Granqvist, C. G., Silverbased crystalline nanoparticles, microbially fabricated. Proc. Natl. Acad. Sci. USA 1999, 96, 13611-4.

15 Mohanpuria, P.; Rana, N. K.; Yadav, S. K., Biosynthesis of nanoparticles: technological concepts and future applications. J. Nanopart. Res. 2008, 10, 507-517.

16 Xiong, L.; Chen, J. J.; Huang, Y. X.; Li, W. W.; Xie, J. F.; $\mathrm{Yu}, \mathrm{H}$. Q., An oxygen reduction catalyst derived from a robust Pd-reducing bacterium. Nano Energy 2015, 12, 33-42.

17 Beveridge, T. J., Role of cellular design in bacterial metal accumulation and mineralization. Annu. Rev. Microbiol. 1989, 43, 147-71.

18 Xiong, L.; Chen, J. J.; Huang, Y. X.; Li, W. W.; Xie, J. F.; $\mathrm{Yu}, \mathrm{H}$. Q., An oxygen reduction catalyst derived from a robust Pd-reducing bacterium. Nano Energy 2015, 12, 33-42.

19 Wu, X.; Zhao, F.; Rahunen, N.; Varcoe, J. R.; AvignoneRossa, C.; Thumser, A. E.; Slade, R. C., A role for microbial palladium nanoparticles in extracellular electron transfer. Angew. Chem. Int. Ed. Eng. 2011, 50, 427-30.

20 Deplanche, K.; Merroun, M. L.; Casadesus, M.; Tran, D. T.; Mikheenko, I. P.; Bennett, J. A.; Zhu, J.; Jones, I. P.; Attard, G. A.; Wood, J.; Selenska-Pobell, S.; Macaskie, L. E., Microbial synthesis of core/shell gold/palladium nanoparticles for applications in green chemistry. J. R. Soc. Interface 2012, 9, 1705-12. 
21 Sobjerg, L. S.; Lindhardt, A. T.; Skrydstrup, T.; Finster, K.; Meyer, R. L., Size control and catalytic activity of bio-supported palladium nanoparticles. Colloids Surf. B Biointerfaces 2011, 85, 373-8.

22 De Corte, S.; Sabbe, T.; Hennebel, T.; Vanhaecke, L.; De Gusseme, B.; Verstraete, W.; Boon, N., Doping of biogenic Pd catalysts with Au enables dechlorination of diclofenac at environmental conditions. Water Res. 2012, 46, 2718-26.

23 De Windt, W.; Aelterman, P.; Verstraete, W. Bioreductive deposition of palladium (0) nanoparticles on Shewanella oneidensis with catalytic activity towards reductive dechlorination of polychlorinated biphenyls. Environ. Microbiol. 2005, 7, 314-25.

24 Sobjerg, L. S.; Gauthier, D.; Lindhardt, A. T.; Bunge, M.; Finster, K.; Meyer, R. L.; Skrydstrup, T., Bio-supported palladium nanoparticles as a catalyst for SuzukiMiyaura and Mizoroki-Heck reactions. Green Chemistry 2009, 11, 2041-2046.

25 Lopez-Haro, M.; Guetaz, L.; Printemps, T.; Morin, A.; Escribano, S.; Jouneau, P. H.; Bayle-Guillemaud, P.; Chandezon, F.; Gebel, G., Three-dimensional analysis of Nafion layers in fuel cell electrodes. Nat. Commun. 2014, 5, 5229.

26 Nakamura, R.; Kai, F.; Okamoto, A.; Newton, G. J.; Hashimoto, K., Self-constructed electrically conductive bacterial networks. Angew. Chem. Int. Ed. Eng. 2009, 48, 508-11.

27 Okamoto, A.; Hashimoto, K.; Nealson, K. H.; Nakamura, R., Rate enhancement of bacterial extracellular electron transport involves bound flavin semiquinones. Proc. Natl. Acad. Sci. U S A 2013, 110, 7856-61.

28 Lovley, D. R., Electromicrobiology. In Annual Review of Microbiology, Vol 66, Gottesman, S.; Harwood, C. S.; Schneewind, O., Eds. 2012; Vol. 66, pp 391-409.

29 Mikheenko, I. P., M. Rousset, S. Dementin, and L. E. Macaskie. Bioaccumulation of palladium by Desulfovibrio fructosivorans wild-type and hydrogenase-deficient strains, Appl Environ Microbiol, 2008, 74: 6144-6.

30 Hennebel, T., S. De Corte, W. Verstraete, and N. Boon. 'Microbial production and environmental applications of $\mathrm{Pd}$ nanoparticles for treatment of halogenated compounds', Curr Opin Biotechnol, 2012, 23: 555-61.

$31 \mathrm{Ng}, \mathrm{C}$. K., T. K. C. Tan, H. Song, and B. Cao. 'Reductive formation of palladium nanoparticles by Shewanella oneidensis: role of outer membrane cytochromes and hydrogenases', RSC Adv, 2013, 3: 22498-503.

32 Babauta, J. T., H. D. Nguyen, and H. Beyenal. Redox and $\mathrm{pH}$ Microenvironments within Shewanella oneidensis MR-1 Biofilms Reveal an Electron Transfer Mechanism, Environ Sci Technol, 2011, 45: 6654-60.

33 Cao, B., L. Shi, R. N. Brown, Y. Xiong, J. K. Fredrickson, M. F. Romine, M. J. Marshall, M. S. Lipton, and H.
Beyenal. Extracellular polymeric substances from Shewanella sp. HRCR-1 biofilms: characterization by infrared spectroscopy and proteomics, Environ Microbiol, 2011, 13: 1018-31.

34 Xiao, Y.; Zhang, E.; Zhang, J.; Dai, Y.; Yang, Z.; Christensen, H. E. M.; Ulstrup, J.; Zhao, F.; Extracellular polymeric substances are transient media for microbial extracellular electron transfer, Science Advances, 2017, 3, e1700623.

35 De Windt, W.; Boon, N.; Siciliano, S. D.; Verstraete, W., Cell density related $\mathrm{H}_{2}$ consumption in relation to anoxic $\mathrm{Fe}(0)$ corrosion and precipitation of corrosion products by Shewanella oneidensis MR-1. Environmental Microbiology 2003, 5, 1192-1202.

36 Wu, R.; Cui, L.; Chen, L.; Wang, C.; Cao, C.; Sheng, G.; $\mathrm{Yu}, \mathrm{H} . ;$ Z Zhao, F., Effects of bio-Au nanoparticles on electrochemical activity of Shewanella oneidensis wild type and DeltaomcA/mtrC mutant. Sci. Rep. 2013, 3, 3307.

37 Hennebel, T.; De Corte, S.; Verstraete, W.; Boon, N., Microbial production and environmental applications of $\mathrm{Pd}$ nanoparticles for treatment of halogenated compounds. Curr. Opin. Biotechnol. 2012, 23, 555-61.

38 Engelbrekt, C.; Jensen, P. S.; Sorensen, K. H.; Ulstrup, J.; Zhang, J. D., Complexity of Gold Nanoparticle Formation Disclosed by Dynamics Study. J. Phys. Chem. C 2013, 117, 11818-11828.

39 Lee, H. J.; Lee, J.; Park, S. M., Electrochemistry of conductive polymers. 45. Nanoscale conductivity of PEDOT and PEDOT:PSS composite films studied by current-sensing AFM. J. Phys. Chem. B 2010, 114, 26606.

40 Parsons, R.; Va ndernoot, T., The Oxidation of Small Organic-Molecules - a Survey of Recent Fuel-Cell Related Research. J Electroanal. Chem. 1988, 257, 9-45.

41 Liang, Z. X.; Zhao, T. S.; Xu, J. B.; Zhu, L. D., Mechanism study of the ethanol oxidation reaction on palladium in alkaline media. Electrochimica Acta 2009, 54, 22032208.

42 Cerritos, R. C.; Guerra-Balcázar, M.; Ramírez, R. F. Ledesma-García, J.; Arriaga, L. G., Morphological Effect of Pd Catalyst on Ethanol Electro-Oxidation Reaction. Materials 2012, 5 (12), 1686-1697.

43 Zhang, H. W.; Chen, D. Z.; Xianze, Y.; Yin, S. B., AnionExchange Membranes for Fuel Cells: Synthesis Strategies, Properties and Perspectives. Fuel Cells 2015, 15, 761-780.

44 Wang, D. M.; Li, J.; Liu, J. R.; Hu, H. Y., Diffusion tensor imaging predicts long-term motor functional outcome in patients with acute supratentorial intracranial hemorrhage. Cerebrovasc Dis. 2012, 34, 199-205.

45 Zhou, W. J.; Lee, J. Y., Particle size effects in Pdcatalyzed electrooxidation of formic acid. J. Phys. Chem. C 2008, 112, 3789-3793. 
TOC
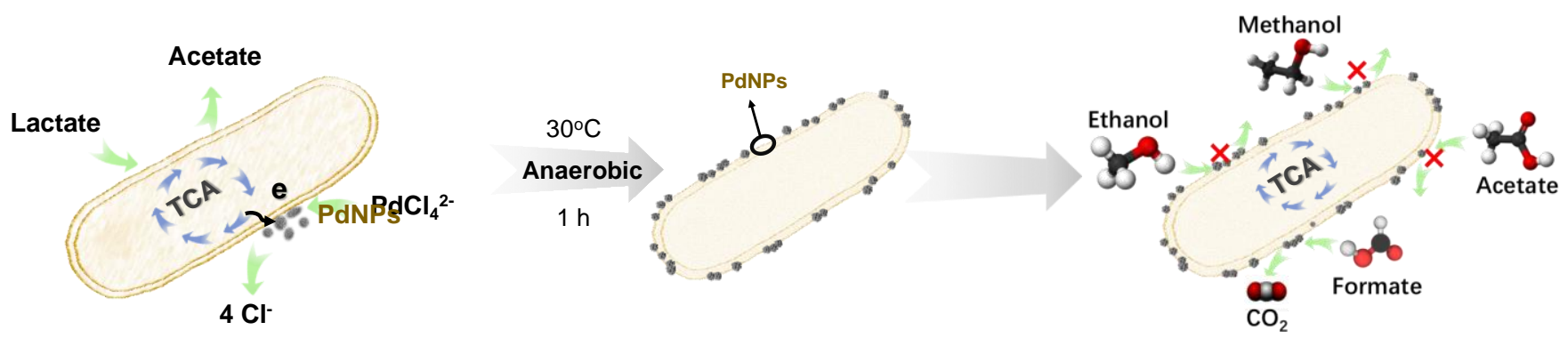


\section{Journal Name}

\section{ARTICLE}

\section{Supporting information}

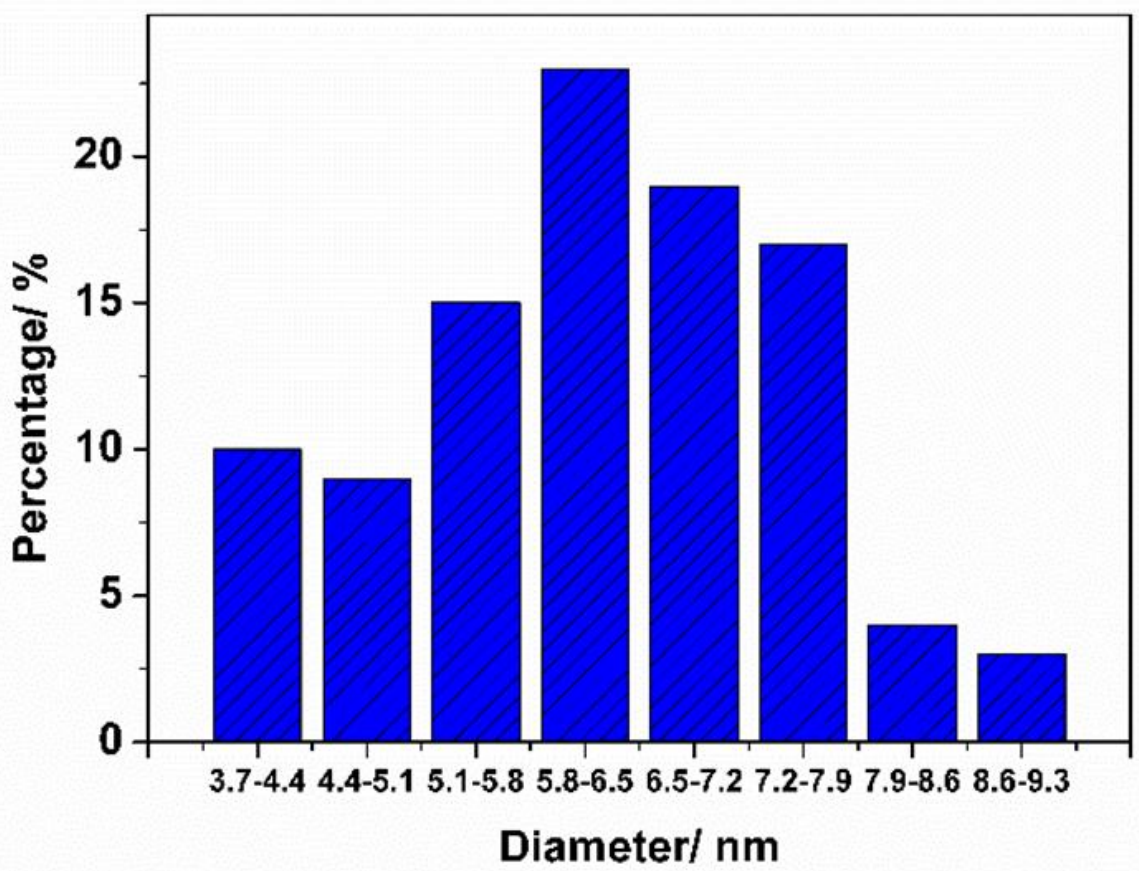

Figure S1. Size distribution of the PdNPs biosynthesized on S. oneidensis MR-1. Data from TEM images (Fig. 3D). 


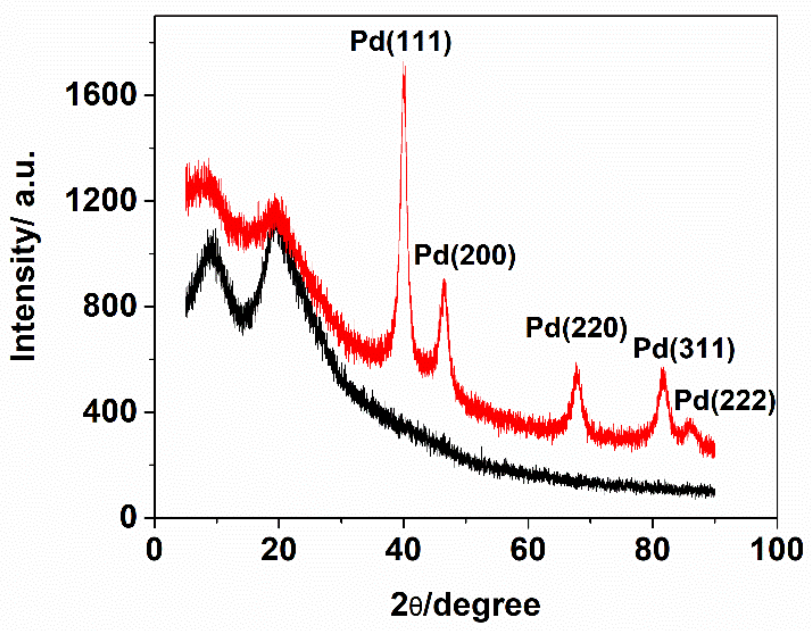

Figure S2. XRD spectra of S. oneidensis MR-1 before (black line) and after (red line) the exposure to 1 $\mathrm{mM} \mathrm{Na} 2\left[\mathrm{PdCl}_{4}\right]$. Each sample was scanned in the $\theta$-range of 5-90 . 


\section{Topography}

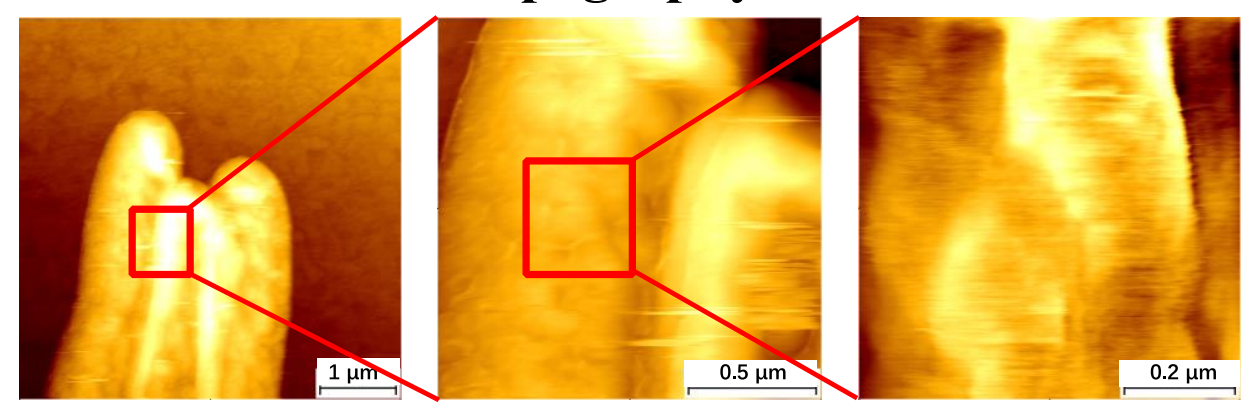

\section{Deflection}
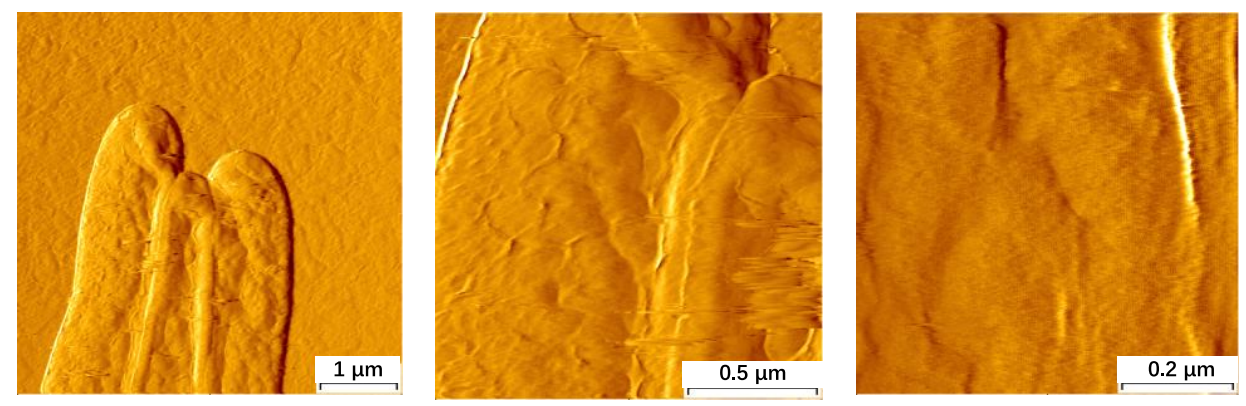

Figure S3. Tapping mode AFM images of S. oneidensis MR-1 cells with PdNPs on Pt sheet $\left(1.0 \times 1.0 \mathrm{~cm}^{2}\right)$. 


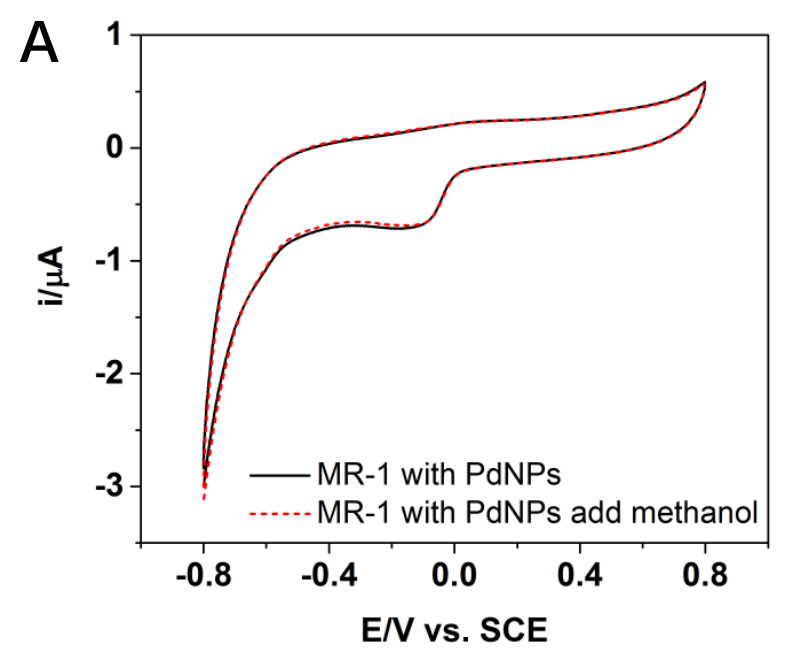

B

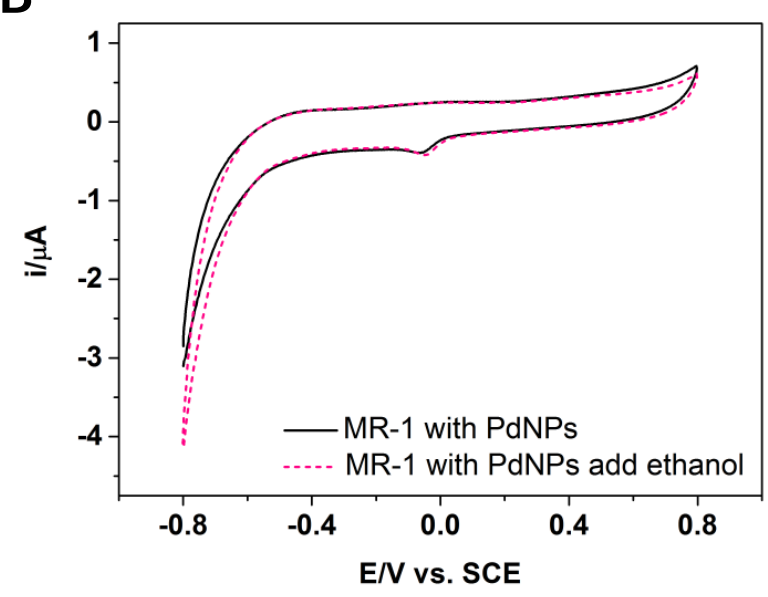

C

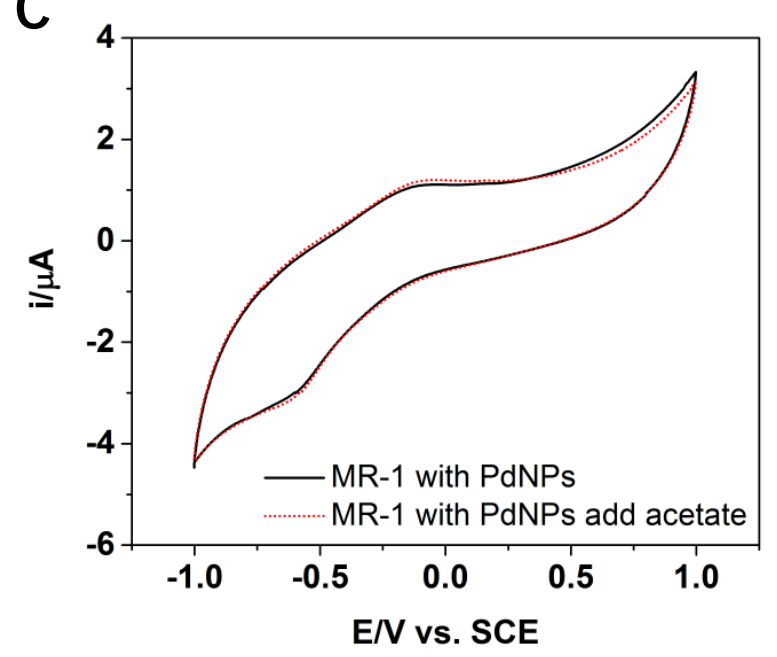

Figure S4. CVs of $S$. oneidensis MR-1 with bio-PdNPs modified GC electrode in $0.10 \mathrm{M} \mathrm{pH} 7.0$ phosphate buffer (solid lines) and in the presence of $100 \mathrm{mM}(\mathrm{A})$ methanol; (B) ethanol and (C) acetate (dotted lines), at a scan rate of $10 \mathrm{mV} / \mathrm{s}$. 


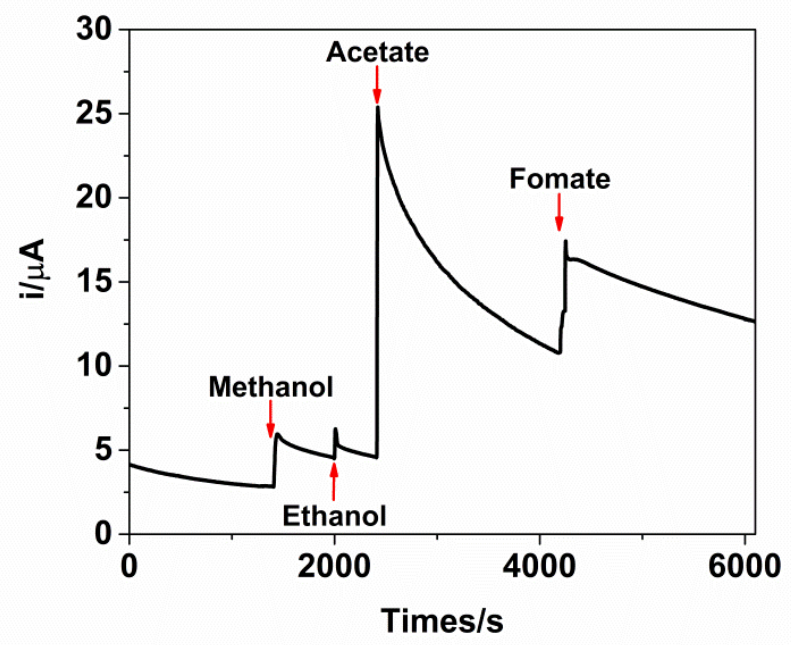

Figure S5. Chronoamperometric curve of methanol, ethanol, acetate, and formate oxidation at electrodeposited Pd modified GC electrode. The potential held at $0.10 \mathrm{~V}$ in $0.10 \mathrm{M} \mathrm{pH} 7.0$ phosphate buffer solution. Final concentrations of methanol, ethanol, acetate, and formate are $0.10 \mathrm{M}$.

\section{Reference}

1. Mikheenko, I. P.; Rousset, M.; Dementin, S.; Macaskie, L. E., Bioaccumulation of palladium by Desulfovibrio fructosivorans wild-type and hydrogenase-deficient strains. Appl Environ Microbiol 2008, 74 (19), 6144-6.

2. Hennebel, T.; De Corte, S.; Verstraete, W.; Boon, N., Microbial production and environmental applications of Pd nanoparticles for treatment of halogenated compounds. Curr Opin Biotechnol 2012, 23 (4), 555-61.

3. Ng, C. K.; Tan, T. K. C.; Song, H.; Cao, B., Reductive formation of palladium nanoparticles by Shewanella oneidensis: role of outer membrane cytochromes and hydrogenases. Rsc Advances 2013, 3 (44), 22498-22503.

4. Babauta, J. T.; Nguyen, H. D.; Beyenal, H., Redox and pH Microenvironments within Shewanella oneidensis MR1 Biofilms Reveal an Electron Transfer Mechanism. Environmental Science \& Technology 2011, 45 (15), 6654-6660.

5. Cao, B.; Shi, L.; Brown, R. N.; Xiong, Y.; Fredrickson, J. K.; Romine, M. F.; Marshall, M. J.; Lipton, M. S.; Beyenal, H., Extracellular polymeric substances from Shewanella sp. HRCR-1 biofilms: characterization by infrared spectroscopy and proteomics. Environ Microbiol 2011, 13 (4), 1018-31. 